\title{
OPTIMIZATION OF CHEMICAL COMPOSITION OF STEEL FOR GEARWEELS OF AGRICULTURAL INDUSTRY ENGINEERING
}

\author{
O. Ye. Semenovskyi, L. L. Titova \\ National University of Life and Environmental Sciences of Ukraine, Ukraine. \\ Speciality of article: 133 - industry engineering. \\ Corresponding authors: l_titova@nubip.edu.ua.
}

Article history: Received-August 2020, Accepted-October 2020.

Bibl. 17, fig. 1, tabl. 1.

Abstract. Development of new steels in mechanical engineering to create alloys with predetermined properties that can minimize material and labor costs during their processing.

Optimization of the chemical composition of the alloy based on the analysis of the impact of complex alloying on the structure and consequently on the manufacturability of steel. This will reduce the level of internal intensities in the heat treatment process.

Based on the analysis of existing trends in mechanical engineering, it is established that the complexity of modern parts of gearweels imposes on the material increasing technological requirements for stamping, machinability, weldability, hardenability, cementation and gouging in the hardening process which explains the need for alloying steel via a certain group of chemical elements. The influence of different compositions of steels for gearweels on the level of internal intensities occurring in parts during heat treatment is studied. The optimal composition of complex-alloyed cementing steel is established.

Key words: alloying, steel, gouging, internal intensities, gearweels, cementation, austenite.

\section{Introduction}

Modern technology makes higher and higher demands in terms of operational properties on construction materials, and serial and mass engineering does in terms of their manufacturability. Development of new compositions with the optimal ratio of physical, mechanical and technological capabilities in the field of cementing steels is complicated due to insufficient information about impact of their composition on these characteristics. In addition, the information available is inconsistent and is mainly of a qualitative nature.

There is still insufficient data on relationship between various properties of cementing steels. This does not allow to predict these properties significantly increasing the efforts required when choosing a material with a given set of properties.

At the same time, insufficient manufacturability of steels for gearweels, namely the high level of gouging during chemical and heat treatment requires additional finishing operations which significantly reduces the economic performance of production.

\section{Formulation of problem}

The practice of operation of root harvesting machines confirms that about $30 \%$ of all failures are on conveyor belts. Conveyors of some machines sometimes do not provide even seasonal operation and need to be repaired or replaced during operation [1]. During unstable operating modes, the traction elements as well as the drive elements are under dynamic load. It is known that significant dynamic loads are observed when starting the conveyor, its output at operating speeds, as well as when stopping or jamming the web [2]. Significant dynamic loads are an undesirable phenomenon and are among the significant factors that accelerate the operation of the conveyor belt and drive elements [3].

During the start-up of the chain conveyor in the traction link of the web there are dynamic loads, the magnitude of which mainly depends on the excess force or duration of start-up [4]. Under the action of pulses that create acceleration, small elastic oscillations occur in the elements of the system [5]. The latter lead to an increase in inertial loads in comparison with their average values, which are determined by the laws of motion of an absolutely rigid body [6]. In the conditions of inconsistency of speeds of all or some elements of the car such sizes, as duration of the periods of start (acceleration) and braking [7], overload of the engine and transfers, can be defined only on the basis of dynamic calculations at which both instability of speed during movement [8], and inertia of masses, involved in the movement process [9].

The aim of the work is to increase the efficiency of chain conveyor by reducing the dynamic loads acting on the drive elements of the bar conveyor and the working bodies of the canvas [10].

\section{Analysis of recent research results}

Choice of steel grade is determined by the operating conditions as well as based on the technological 
capabilities of equipment [11]. A comprehensive analysis of steel grades used for heavy-duty gearweels is performed in [1]. Analyzing this work, we can conclude that the choice of material largely determines use of the appropriate reinforcement technology [12]. Medium-carbon steels from which high-modulus gearweels are made are subject to surface reinforcement via reinforcement by high frequency currents followed by low or medium tempering [13]. This process is highly productive. In addition, it is characterized by a minimum level of gouging of parts in the heat treatment process which significantly simplifies the finishing operations [14].

However, comparative studies of the microstructure, thickness and hardness of the reinforced layer, internal intensities, contact fatigue strength, wear resistance [15], the effect of tempering temperature on the hardness of the surface layer of gearweels reinforced by volumetric reinforcement, induction surface reinforcement and chemical heat treatment have showed that induction reinforcement can not be used for critical parts due to possibility of such phenomena as self-tempering, edge and root cracking of teeth, overheating, melting and spotting.

Use of chemical-thermal treatment provides an increased performance of the reinforced layer in comparison to induction surface reinforcement $[2,5]$. It is noted that the surface reinforcement via chemical-thermal treatment doubles the service life of gearing versus the volumetric hardening [16]. Therefore, the chemical heat treatment should be considered as the most promising technology for gearweels' strengthening.

Japan has been a recognized leader in the development of cementing steels for the last two decades $[3,4]$. To prevent appearance of anomalous structures during chemical-thermal treatment, the steel with the following content of alloying elements (in percent) is proposed: carbon $(0.10 \ldots 0.40)$, silicon $(0.50)$, manganese (0.05), chromium (0.35), aluminum (0.01), nitrogen (0.0045), nickel $(0.20 \ldots 0.50)$, or molybdenum $(0.10 \ldots 0.25)$, as well as boron $(0.003 \ldots 0.005)$, or niobium $(0.01 \ldots 0.15)$, vanadium $(0.01 \ldots 0.10)$. This reduces the time of cementation and increases the fatigue strength.

It is observed by analyzing the chemical compositions of cementing steels that there is a tendency to reduce the content of nickel in steel. This is dictated primarily by economic considerations. Decrease in content of alloying elements such as silicon, manganese and chromium in steel is determined by their high chemical activity against oxygen which increases the internal oxidation at high temperatures occurring during cementation and, consequently, reduces the full range of performance [17]. The presence of niobium, cerium, titanium, vanadium, and boron alloys in chemical compositions is explained by desire of the above studies' authors to improve not only mechanical properties but also technological requirements for new materials.

\section{Purpose of research}

To improve economic performance of production in mechanical engineering by enhancing the manufacturability of steel by complex alloying.
The method of determining internal intensities is used to determine the value of internal intensities in the reinforced layer of complex-alloy steels after chemicalheat treatment.

The point of the measuring internal intensities method is that the intensities on two opposite sides of a sample are mutually balanced in the initial state. When removing the reinforced layer from one of the surfaces to a certain depth, a sample bends under the action of internal intensities of the reinforced layer of the opposite side.

\section{Results of research}

The research is carried out on samples and completed parts made of serial steels and complex-alloy steel. The method of repeated etching with $20 \%$ nitric acid ethanol solution is used to reduce the impact of mechanical factors on the research accuracy when removing the reinforced layer.

The formula for calculating the value of internal intensities is based on the dependence of the bending torque caused by unbalanced compressive intensities in the direction of the longitudinal axis of a bar after removing a certain layer on the opposite side of a sample and mechanical properties of a material. Based on this:

$$
M_{x}=\frac{E_{I} \cdot I}{\rho},
$$

where: $\mathrm{Mx}$ - torque; EI - elasticity modulus of the first type; I - moment of inertia of the cross section of the bar; $\rho-$ the deflection radius of the sample;

In turn:

$$
\rho=\left(\frac{l}{2}\right)^{2}+(\rho-\Delta x)^{2} ; M_{x}=\frac{N_{x} \cdot h}{2} ; I=\frac{b h^{3}}{12} ;
$$

where: $\mathrm{Nx}$ - the force caused by the compressive intensity in the direction of the longitudinal axis of a bar;

$\mathrm{x}$ - the amount of deflection after removal of the layer in which the intensities are determined;

$\mathrm{h}-\mathrm{a}$ bar thickness after removing the layer in which the intensity is determined;

b - a bar width;

1 - a bar length;

given that

$$
\sigma_{H}=\frac{N_{X}}{b \Delta h}
$$

where: $\sigma_{H}-$ intensity in the investigated layer;

$\mathrm{b} \Delta \mathrm{h}$ - the cross-sectional area of the removed layer; we can derive the following dependence to determine the internal intensities in the reinforced layers:

$$
\sigma_{H}=\frac{4 E \cdot h^{2} \cdot \Delta x}{3 l^{2} \cdot \Delta h}
$$

An optical instrumental microscope UIM-1 is used to increase the accuracy of the proposed method when measuring the deflection. This ensures the accuracy of measurements up to $-10^{-4} \mathrm{~mm}$.

Grooving of parts during heat treatment is also measured. Change of an angle of inclination of the gearweel tooth on the gearweel measuring device 1500 is determined. To ensure comparability of the results, the measurement length is $100 \mathrm{~mm}$. Repeated experiments allow an error reduction down to $2 \%$.

In addition to determining of the parts' grooving during the chemical-thermal treatment, the intensities' distribution in the cemented layer is also studied as a 
consequence of the processes that occur during reinforcement. Steels with the same compositions of alloying elements as for the determining hardenability and grooving are selected. This is done to establish the relationship with other parameters that are determined during the study of processes occurring during bending of parts as well as to study the residual intensities in the reinforced layer. The results of samples' measurement after etching part of the cemented layer along with the calculations of internal intensities in the extracted layers of metal are summarized in table 1 .

Table 1. Distribution of internal stresses in the reinforced layer.

\begin{tabular}{|c|c|c|c|}
\hline Steel brand & Measurament depth, $\mathrm{mm}$ & Deflection change, $\mathrm{mkm}$ & Tensions $\sigma, k P a$ \\
\hline \multirow{5}{*}{$12 \mathrm{HN} 3 \mathrm{~A}$} & 0.1 & 21.1 & 86.7 \\
\hline & 0.3 & 19.4 & 78.4 \\
\hline & 0.5 & 10.9 & 41.8 \\
\hline & 0.7 & 4.1 & 16.2 \\
\hline & 0.9 & 1.2 & 4.3 \\
\hline \multirow{5}{*}{ 15HGN4 } & 0.1 & 23.8 & 98.2 \\
\hline & 0.3 & 22.9 & 90.2 \\
\hline & 0.5 & 9.8 & 38.2 \\
\hline & 0.7 & 3.9 & 14.9 \\
\hline & 0.9 & 1.5 & 5.2 \\
\hline \multirow{5}{*}{$15 \mathrm{HGN}$} & 0.1 & 9.9 & 46.5 \\
\hline & 0.3 & 6.6 & 27.9 \\
\hline & 0.5 & 5.5 & 22.7 \\
\hline & 0.7 & 1.7 & 6.7 \\
\hline & 0.9 & 1.1 & 3.5 \\
\hline \multirow{5}{*}{ 15HGNBTCH } & 0.1 & 19.7 & 79.9 \\
\hline & 0.3 & 11.0 & 43.7 \\
\hline & 0.5 & 5.3 & 20.7 \\
\hline & 0.7 & 1.1 & 4.0 \\
\hline & 0.9 & 0.1 & 0.4 \\
\hline \multirow{5}{*}{ 18HGT } & 0.1 & 15.3 & 63.2 \\
\hline & 0.3 & 13.9 & 55.4 \\
\hline & 0.5 & 3.7 & 14.2 \\
\hline & 0.7 & 3.6 & 13.5 \\
\hline & 0.9 & 1.1 & 4.0 \\
\hline
\end{tabular}

The steel 15HGN4 has the highest intensity on the surface. Whereas the steel 12HN3A has a lower level of residual intensity which is explained by a decrease in the degree of its alloying. The lowest residual intensities in the surface layer are discovered in the steel 15HGN which contains the least amount of Nickel. In the 15HGNBTCH steel developed by us, the intensities in the surface layer are lower than in the high-alloy steel 15HGN4 and are almost at the same level with the serial steel 12HN3A. It is hard to compare degrees of alloying of these steels because titanium and niobium in small quantities strengthen steel much more than nickel does.

Comparison of the residual intensity levels in the steels $15 \mathrm{HGN}$ and $18 \mathrm{HGT}$ with a lower content of alloying elements could confirm the above considerations. As we can see, the steel containing only $0.05 \%$ titanium has 1.5 times higher level of internal intensities in the surface layer than the steel with $1 \%$ Nickel.

However, if we compare internal intensities in the experimental steel 15HGNBTCH and the serial steel 12HN3A with their mechanical properties, then there are some inconsistencies. I.e. steels with almost the same level of internal intensities have different levels of strength characteristics. This is due to the fact that the mechanical characteristics are determined on samples reinforced via volumetric reinforcement with low tempering, and the surface layer which determined the internal intensities is 
strengthened by cementation and, as a result, differs in the chemical composition and structure.

In addition, according to the working hypothesis, the magnitude of the residual internal intensities should indirectly relate to the propensity of steel to gouge. But if we compare the obtained data with the results of studies of the propensity of steel to gouging obtained both in laboratory and in mass production, we will see the discrepancy between the results of these studies.

In any case, let's define intensities value as their identified maximum on the surface. However, the deformation of a sample or parts is affected by intensities occurring throughout the cross section. For this reason, intensities are identified not only on the surface but also along the entire depth of the reinforced layer. Graphical dependences are constructed (Fig. 1) to study the nature of the change in the absolute value of the residual internal compressive intensities.

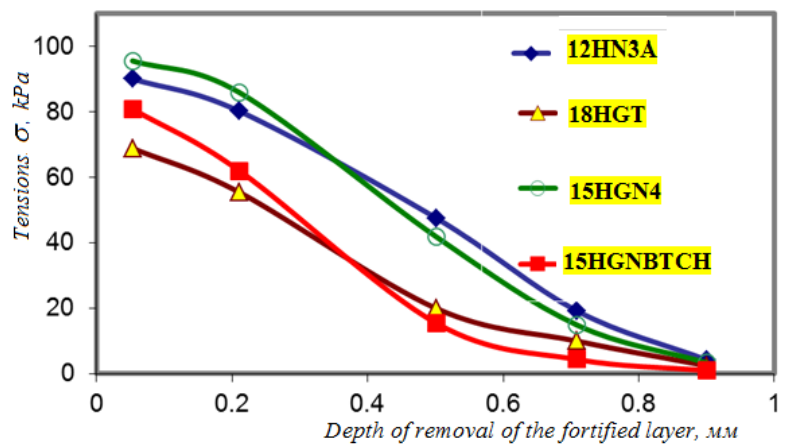

Fig. 1. Distribution of residual compressive intensities in the reinforced layer.

The nature of the obtained curves suggests that the complex-alloy steel has a sharper decrease in intensities levels as it moves away from the surface compared with the serial steel $12 \mathrm{HN} 3 \mathrm{~A}$.

Computer processing of the summarised intensities of the entire reinforced layer shows that this index is 1.5 times higher in the serial steel 12KHN4A.

Development of a high-tech steel is a task of not only qualitative but also quantitative measurament of such technological characteristics as the propensity of steels to gouge in the process of chemical heat treatment. Given that and based on the analysis of comparative studies of gouging parts from different steels the results of which are presented in the histograms in fig. 1, it is proposed to introduce a single characteristic that determines the susceptibility of steel to deformation during reinforcement. It is a coefficient determined as a ratio between the number of parts embedded in the allowable size of the gutter (according to the technical documentation) to the number of parts not embedded in the allowable technical documentation deviations (defective parts). Such a quantitative characteristic is in this case the Riemann integral (it is a curvilinear trapezoid area in terms of Darboux sum boundary). It is done using the indicatorfunction of a variable " $\mathrm{x}$ " belonging to a set. The latter is defined as follows.

$$
\chi_{\mathrm{A}}(\mathrm{x})=\left\{\begin{array}{ll}
1, & \mathrm{x} \in \mathrm{A} \\
0, & \mathrm{x} \notin \mathrm{A}
\end{array} .\right.
$$

Therefore, we can represent a step graph of the function $\mathfrak{I}(\mathrm{x})$ :

$$
\mathfrak{I}(\mathrm{x})=\sum_{i=1}^{m}\left(n_{i} \chi_{\left(\mathrm{a}_{i} ; \mathrm{a}_{i+1}\right)}(s)\right)
$$

Let $\mathrm{nj}$ be a value of the function on a semi-closed interval $\left(a_{j}, \mathrm{a}_{j+1}\right]$.

The introduced characteristic is then could be written in the following form:

$$
\begin{aligned}
& \mathfrak{R}(x)=\mathfrak{R}(\mathfrak{I}(\mathrm{x}))=\frac{\int_{\mathrm{x}}^{b}\left(\sum_{i=1}^{m}\left(n_{i} \chi_{\left(\mathrm{a}_{i} ; \mathrm{a}_{i+1}\right)}(s)\right) \mathrm{ds}\right)}{\int_{\mathrm{a}}^{\mathrm{x}}\left(\sum_{i=1}^{m}\left(n_{i} \chi_{\left(\mathrm{a}_{i} ; \mathrm{a}_{i+1}\right)}(s)\right) \mathrm{ds}\right)}= \\
& \frac{\sum_{i=j+1}^{m: \mathrm{x} \in\left(a_{j}, \mathrm{a}_{j+1}\right]}\left(n_{i} \Delta \mathrm{a}_{i+1}+\frac{n_{j}\left(\mathrm{a}_{j+1}-\mathrm{x}\right)}{m-j}\right)}{\sum_{\substack{\mathrm{j}: \mathrm{x} \in\left(a_{j}, \mathrm{a}_{j+1}\right] \\
\mathrm{j}-1}}\left(n_{i} \Delta \mathrm{a}_{i+1}+\frac{n_{j}\left(\mathrm{x}-\mathrm{a}_{j}\right)}{m-j}\right)}
\end{aligned}
$$
variable $\mathrm{x}$ belonging to a set $\mathrm{A}$;

$\mathrm{nj}-\mathrm{a}$ value of the function on a semi-closed interval $\left(a_{j}, \mathrm{a}_{j+1}\right], \quad \mathfrak{I}(\mathrm{x})=\sum_{i=1}^{m}\left(n_{i} \chi_{\left(\mathrm{a}_{i} ; \mathrm{a}_{i+1}\right)}(s)\right)$ - a functional dependence which corresponds to a step graph based on the experimental data.

For the steel $12 \mathrm{HN} 3 \mathrm{~A}$, the calculations are as follows:

$$
\begin{aligned}
& \Re(x)=\left\{\begin{array}{l}
\frac{101-18 x}{18 x}, x \in(0,1] \\
\frac{107-24 x}{24 x-6}, x \in(1,2] \\
\frac{115-28 x}{28 x-14}, x \in(2,3] \\
\frac{79-16 x}{16 x+22}, x \in(3,4] \\
\frac{51-9 x}{9 x+50}, x \in(4,5] \\
\frac{36-6 x}{6 x+65}, x \in(5,6]
\end{array}\right. \\
& \Re(x)=\left\{\begin{array}{l}
\frac{101-18 x}{18 x}, x \in(0,1] \\
\frac{107-24 x}{24 x-6}, x \in(1,2] \\
\frac{115-28 x}{28 x-14}, x \in(2,3] \\
\frac{79-16 x}{16 x+22}, x \in(3,4] \\
\frac{51-9 x}{9 x+50}, x \in(4,5] \\
\frac{36-6 x}{6 x+65}, x \in(5,6]
\end{array}\right.
\end{aligned}
$$

And for the steel $15 \mathrm{HGNBTCH}$,

$$
\Re(x)=\left\{\begin{array}{l}
\frac{29(1-x)+61}{29 x}, x \in(0,1] \\
\frac{48(2-x)+23}{48(x-1)+29}, x \in(1,2] \\
\frac{21(3-x)+2}{21(x-2)+77}, x \in(2,3] \\
\frac{2(4-x)}{2(x-3)+98}, x \in(3,4]
\end{array}\right.
$$




$$
\begin{gathered}
x=\left\{\begin{array}{l}
\frac{90}{29\left(R_{0}+1\right)}, x \in(0,1] \\
\frac{119+19 R_{0}}{48\left(R_{0}+1\right)}, x \in(1,2] \\
\frac{65-35 R_{0}}{28\left(R_{0}+1\right)}, x \in(2,3] \\
\frac{2\left(1-23 R_{0}\right)}{\left(R_{0}+1\right)}, x \in(3,4]
\end{array}\right. \\
R_{0}=0.03 \Rightarrow x \geq 2,956 .
\end{gathered}
$$

In our specific case, with the allowable percentage of quantitative characteristics of defective and non-defective parts within $-3 \%$, the steel 15 HGNBTCH having a low propensity to gouge will provide tolerances of $0.029 \mathrm{~mm}$, and the steel 12HN3A will do $0.055 \mathrm{~mm}$.

And in the case when the steel $12 \mathrm{HN} 3 \mathrm{~A}$ provides the same tolerances as the complex-alloyed, the number of defective parts will be up to $30 \%$.

\section{Conclusions}

1. Complex alloying with titanium, niobium and cerium allows to increase the manufacturability of steel and, as a consequence, to enhance the economic performance of production by reducing the number of finishing operations.

2. It is established during the research that the level of gouging of parts in the process of chemical-thermal treatment is directly dependent on the level of internal intensities.

3. It is necessary to minimize the propensity of the alloy to grow austenitic grain for cementing steels which in the process of chemical-heat treatment are exposed to longterm high temperatures. This is achieved by complex alloying elements such as titanium and niobium that form a carbide phase resistant to high temperatures.

\section{References}

1. Matyushenko I. Y., Kostenko D. M. (2016) Advanced production technologies - the key to quality transformation and growth of high-tech exports of Ukraine until 2030. Problems of economics. № 2. 21-27.

2. Krylova S. E., Tryakina N. Yu., Priymak E. Yu., Sokolov S. O., Gryzunov V. I. (2013). Rationalization of parameters of heat treatment of 70X3G2VTB steel based on studies of phase composition. Metallurgy and heat treatment of metals. № 1. 12-19.

3. Nazyuta L. Yu. (2013). Impact of boron on technological properties of medium-carbon structural steels of ordinary assortment. Bulletin of the Azov Technical University.

4. Safonov B. P., Begova A. V. (2014). The choice of steels for parts under different loading conditions. Bulletin of the Perm National Polytechnic University. № 1. 17-22.

5. Poduzov D.P. (2017). Investigation of transformations of the structure and properties of the system-alloyed low-carbon steel 12X3G2MFS industrial smelting. Bulletin of the Perm National Polytechnic University. № 1. 8-12.
6. Gorynin V. I. (2013). Increase in resistance to brittle fracture of the pearlitic and martensitic steels under thermal action on the morphology of the carbide phase. Metallurgy and heat treatment of metals. № 10.

7. Rogovskii I. L., Titova L. L., Trokhaniak V. I., Solomka O. V., Popyk P. S., Shvidia V. O., Stepanenko S. P. (2019). Experimental studies of drying conditions of grain crops with high moisture content in low-pressure environment. INMATEH. Agricultural Engineering. Bucharest. 57(1). 141-146.

8. Loveikin V., Romasevych Y., Shymko L., Ohiienko M., Duczmal W., Potwora W., Titova L., Rogovskii I. (2020). Agrotronics and optimal control of cranes and hoisting machines: monograph. Opole: The Academy of Management and Administration in Opole. 164.

9. Zagurskiy O., Ohiienko M., Pokusa T., Zagurska S., Pokusa F., Titova L., Rogovskii I. (2020). Study of efficiency of transport processes of supply chains management under uncertainty. Monograph. Opole: The Academy of Management and Administration in Opole. 162.

10. Rogovskii I. L., Titova L. L., Trokhaniak V.I., RosamahaY Y.O., Blesnyuk O. V., Ohiienko M. M. Ohiienko A. V. (2019). Engineering management of twophase coulter systems of seeding machines for implementing precision farming technologies. INMATEH. Agricultural Engineering. 2019. 58(2). 137-146. doi: 10.35633/INMATEH-58-15.

11. Romaniuk W., Polishchuk V., Marczuk A., Titova L., Rogovskii I., Borek K. (2018). Impact of sediment formed in biogas production on productivity of crops and ecologic character of production of onion for chives. Agricultural Engineering (wir.ptir.org). Krakow. Poland. 22(1). 105125. https://doi.org/10.1515/agriceng-2018-0010.

12. Gorobets V. G., Trokhaniak V. I., Rogovskii I. L., Titova L. L., Lendiel T. I., Dudnyk A. O., Masiuk M. Y. (2018). The numerical simulation of hydrodynamics and mass transfer processes for ventilating system effective location. INMATEH. Agricultural Engineering. 56(3). 185-192.

13. Rogovskii I., Titova L., Trokhaniak V., Trokhaniak O., Stepanenko S. (2019). Experimental study in a pneumatic microbiocature separator with apparatus camera. Bulletin of the Transilvania University of Brasov, Series II: Forestry, Wood Industry, Agricultural Food Engineering. 12(1). 117-128.

14. Titova L. L., Rogovsky I. L. (2014). Methodical provisions of the need for mobile means of maintenance of forest MEZ. Scientific Herald of National University of Life and Environmental Science of Ukraine. Series: Technique and energy of APK. Kyiv. 196(3). 146-152.

15. Titova L. L., Rogovsky I. L. (2014). Methods of maintenance of forest machines. Bulletin of the Petro Vasylenko Kharkiv National Technical University of Agriculture. Kharkiv. 155. 132-137.

16. Titova L. L., Rogovskii I. L.

(2015). Substantiation of technical measures to maintain the efficiency of machines for forestry work. Bulletin of the Petro Vasylenko Kharkiv National Technical University of Agriculture. Kharkiv. 160. 189-195.

17. Titova L. L., Rogovsky I. L. (2015). Analysis of periodicity of maintenance of machines for forestry works. 
Scientific Herald of National University of Life and Environmental Science of Ukraine. Series: Technique and energy of APK. Kyiv. 2015. 212(1). 322-328.

\section{Список літератури}

1. Матюшенко І. Ю., Костенко Д. М. Передові виробничі технології - ключ до якісної трансформації та зростання високотехнологічного експорту України до 2030p. Проблеми економіки. 2016. № 2. С. 21-27.

2. Крылова С. Е., Трякина Н. Ю., Приймак Е. Ю., Соколов С. О., Грызунов В.И. Рационализация параметров термической обработки стали 70Х3Г2ВТБ на основе исследований фазового состава. Металловедение и термическая обработка металлов. 2013. № 1. С. 12-19.

3. Назюта Л. Ю. Вплив бору на технологічні властивості середньовуглецевих конструкційних сталей рядового сортаменту. Вісник Приазовського технічного університету. 2013.

4. Сафонов Б. П., Бегова А. В. Выбор сталей для деталей в различных условиях нагружения. Вестник Пермского национального политехнического университета. 2014. № 1. С. 17-22.

5. Подузов Д. П. Исследование превращений структуры и свойств системно-легированой низкоулеродистой стали 12Х3Г2МФС промышленной выплавки. Вестник Пермского национального политехнического университета. 2017. № 1. C. 8-12.

6. Горынин В. И. Повышение сопротивляемости хрупкому разрушению перлитных и мартенситных сталей при термическом воздействии на морфологию карбидной фазы. Металловедение и термическая обработка металлов. 2013. № 10.

7. Rogovskii I. L., Titova L. L., Trokhaniak V. I., Solomka O.V., Popyk P. S., Shvidia V. O., Stepanenko S. P. Experimental studies of drying conditions of grain crops with high moisture content in low-pressure environment. INMATEH. Agricultural Engineering. Bucharest. 2019. Vol. 57. No 1. P. 141-146.

8. Loveikin V., Romasevych Y., Shymko L., Ohiienko M., Duczmal W., Potwora W., Titova L., Rogovskii I. Agrotronics and optimal control of cranes and hoisting machines: monograph. Opole: The Academy of Management and Administration in Opole. 2020. 164 p.

9. Zagurskiy O., Ohiienko M., Pokusa T., Zagurska S., Pokusa F., Titova L., Rogovskii I. Study of efficiency of transport processes of supply chains management under uncertainty. Monograph. Opole: The Academy of Management and Administration in Opole. 2020. 162 p.

10. Rogovskii I. L., Titova L.L., Trokhaniak V. I., Rosamaha Yu. O., Blesnyuk O. V., Ohiienko M. M. Ohiienko A. V. Engineering management of two-phase coulter systems of seeding machines for implementing precision farming technologies. INMATEH. Agricultural Engineering. 2019. Bucharest. Vol. 58. No 2. P. 137-146. doi: 10.35633/INMATEH-58-15.

11. Romaniuk W., Polishchuk V., Marczuk A., Titova L., Rogovskii I., Borek K. Impact of sediment formed in biogas production on productivity of crops and ecologic character of production of onion for chives. Agricultural Engineering (wir.ptir.org). Krakow. Poland. 2018. Vol. 22. №1. P. 105125. https://doi.org/10.1515/agriceng-2018-0010.

12. Gorobets V. G., Trokhaniak V. I., Rogovskii I. L., Titova L. L., Lendiel T. I., Dudnyk A. O., Masiuk M. Y. The numerical simulation of hydrodynamics and mass transfer processes for ventilating system effective location. INMATEH. Agricultural Engineering. 2018. Bucharest. Vol. 56. No 3. P. 185-192.

13. Rogovskii I., Titova L., Trokhaniak V., Trokhaniak O., Stepanenko $S$. Experimental study in a pneumatic microbiocature separator with apparatus camera. Bulletin of the Transilvania University of Brasov, Series II: Forestry, Wood Industry, Agricultural Food Engineering, 2019. Vol. 12 (1). P. 117-128.

14. Тітова Л. Л., Роговський І. Л. Методичні положення потреби в мобільних засобах техобслуговування лісових МЕЗ. Науковий вісник Національного університету біоресурсів i природокористування України. Серія: техніка та енергетика АПК. Київ. 2014. Вип. 196, ч. 3. С. 146-152.

15. Тітова Л. Л., Роговський І. Л. Методи технічного обслуговування лісових машин. Вісник Харківського національного технічного університету сільського господарства імені Петра Василенка. Харків. 2014. Вип. 155. С. 132-137.

16. Тітова Л. Л., Роговський І. Л. Обгрунтування технічних заходів підтримання працездатності машин для лісотехнічних робіт. Вісник Харківського національного технічного університету сільського господарства імені Петра Василенка. Харків. 2015. Вип. 160. С. 189-195.

17. Тітова Л. Л., Р Роговський І. Л. Аналіз періодичності техобслуговування машин для лісотехнічних робіт. Науковий вісник Національного університету біоресурсів і природокористування України. Серія: техніка та енергетика АПК. Київ. 2015. Вип. 212, ч. 1. С. 322-328.

\section{ОПТИМІЗАЦІЯ ХІМІЧНОГО СКЛАДУ СТАЛЕЙ ДЛЯ ШЕСТЕРЕНЬ СІЛЬСЬКОГОСПОДАРСЬКОГО МАШИНОБУДВАННЯ \\ О. С. Семеновський, Л. Л. Тітова}

Анотація. Розробка нових сталей у машинобудуванні для створення сплавів із заданими властивостями, що дозволяють мінімізувати матеріальні та трудові витрати під час їх обробки.

Оптимізація хімічного складу сплаву на основі аналізу впливу складного легування на структуру i, отже, на технологічність сталі. Це зменшить рівень внутрішньої інтенсивності в процесі термообробки.

На основі аналізу існуючих тенденцій у машинобудуванні встановлено, що складність сучасних деталей зубчастих коліс накладає на матеріал зростаючі технологічні вимоги до штампування, механічної оброблюваності, зварюваності, загартовуваності, цементації та шліфуванню в процесі затвердіння, що пояснює необхідність легування сталі за допомогою певної групи хімічних елементів. Досліджено вплив різних складів сталей для зубчастих коліс на рівень внутрішніх інтенсивностей, що виникають в деталях при термічній обробці. 
Встановлено оптимальний склад комплексолегованої цементуючої сталі.

Ключові слова: легування, сталь, шліфування, внутрішня інтенсивність, зубчасті колеса, цементація, аустеніт.

\section{ОПТИМИЗАЦИЯ ХИМИЧЕСКОГО СОСТАВА СТАЛИ ДЛЯ ШЕСТЕРЕН \\ СЕЛЬСКОХОЗЯЙСТВЕННОГО МАШИНОСТРОЕНИЯ \\ О. Е. Семеновский, Л. Л. Титова}

Аннотация. Разработка новых сталей в машиностроении для создания сплавов с заданными свойствами, позволяющими минимизировать материальные и трудовые затраты при их обработке.

Оптимизация химического состава сплава на основе анализа влияния сложного легирования на структуру и, следовательно, на технологичность стали. Это уменьшит уровень внутренней интенсивности в процессе термообработки.

На основе анализа существующих тенденций в машиностроении установлено, что сложность современных деталей зубчатых колес накладывает на материал растущие технологические требования к штамповке, механической обрабатываемости, свариваемости, загартовуваности, цементации и шлифовке в процессе затвердевания, что объясняет необходимость легирования стали с помощью определенной группы химических элементов. Исследовано влияние различных составов сталей для зубчатых колес на уровень внутренних интенсивностей, возникающих в деталях при термической обработке. Установлен оптимальный состав комплексолегованои цементирующей стали.

Ключевые слова: легирования, сталь, шлифовка, внутренняя интенсивность, зубчатые колеса, цементация, аустенит.

О. Є. Семеновський ORCID 0000-0001-8953-2158.

Л. Л. Тітова ORCID 0000-0001-7313-1253. 
